\title{
The Promise and Responsibility of Community Finance
}

\author{
BY ELLEN SEIDMAN AND MARK HUELSMAN
}

W

e are in the midst of a period of intense and frustrating contradictions for our country in general and for community finance. Just take these examples:

- In an economy built on and sustained by credit, consumers now understand the importance of reducing debt levels, while businesses are increasingly having trouble getting the credit they need to survive, much less to get the economy growing again.

- Meanwhile, consumers who are seeking to pull in from excessive credit in order to save are increasingly faced with sudden unemployment that may force them to tap into their savings, including retirement funds.

- In the effort to prevent the collapse of the financial system, the government has extended its hand and wallet to large financial institutions and investment banks, most of which contributed mightily to the current crisis. At the same time, responsible smaller institutions, which have served their communities well and continue to do so, have largely been shut out. These include the vast majority of banks, credit unions, and all but a very few Community Development Financial Institutions (CDFIs).

- Finally, the need for community development finance has never been greater, yet the resources to support it have never been under more pressure, generating both short-term liquidity challenges and long-term funding concerns for CDFIs.

The challenge for community development finance is to some extent an extension of what the industry has faced for the past several years. Since at least 2001, Community Reinvestment Act (CRA)-based support of CDFIs has become harder to come by, pressured by a combination of demands for market returns, consolidation of the banking industry, and general disinterest in CRA. The CRA is a U.S. federal law designed to encourage commercial banks and savings associations to meet the needs of borrowers in their communities, including low- and moderate-income neighborhoods. More recently, philanthropies and pension funds, the source of many grants and investments in CDFIs, are facing enormous setbacks in a shaky and declining market, leading them to pull back-or at least not increase-CDFI investments. State and local governments face enormous budgetary concerns, drying up precious resources for community financial institutions. And capital markets are frozen, which has put at least a temporary stop to innovative financial initiatives that have been championed in the past.

Even resources dedicated to community finance are pressured. Both the CDFI Fund's investment programs and the New Markets Tax Credit have been vastly oversubscribed in recent rounds, and high-quality applicants turned away. Some relief has come in the recent stimulus bill, but it is unlikely to be enough. The Low Income Housing Tax Credit market, a source of both affordable housing and revenues for many CDFIs is in total disarray with the disappearance from the market of Fannie Mae and Freddie Mac (not to mention the lack of taxable income in general). And both the generally low, flat yield curve and financial pressures on CDFI borrowers have hurt, respectively, CDFI spreads and loan performance.

\section{Community Finance Success Factors}

With these contradictions in mind, it is worth reviewing some of what has made community financial institutions - CDFIs as well as community banks and credit unions effective in the long-term and, in some cases, impressive performers in the short term. In 2008, a year that saw the toppling of a number of major financial institutions, only one CDFI bank failed. And the failure rate among banks with under $\$ 1$ billion in assets was one-seventh the failure rate for those with assets over $\$ 1$ billion. There are five crucial factors behind this success.

First, CDFIs and community banks and credit unions have dedicated and loyal leadership and staff. These institu- 
tions are staffed by employees who are mission-oriented and loyal to the community that they serve.

Second, these institutions forge a local presence by understanding the needs of individual customers, opportun ties in the community, and the community's business and power structure.

Third, they maintain financial flexibility, coupled with a high degree of ndidual attention when underwriting. Rather the simply judging a pots rating alone, CDHs, as well as nany community banks and on actual knowledge of each individual borrower's situation.

Fourth, CDFIs and community banks and credit unions work with their borrowers, combining understanding of individual circumstances with discipline and persistence, once loans are made. As unregulated institutions, CDFI loan and venture capital funds also have greater flexibility to restructure and extend loans when appropriate.

Finally, CDFI loan funds in particular have shown an eagerness to experiment with levels and types of risk and financial structures to meet their borrowers' needs-while retaining the risk on the balance sheet, and so having a strong interest in the borrowers success. This provides them an advantage in servicing community finance needs compared to the more highly regulated banks and credit unions, even those that are certified CDFIs.

\section{Why Hasn't This Story}

\section{Been Told?}

Notwithstanding the strong performance in the community of CDFIs and other community-focused financial institutions, there has been little recognition of their positive role during the public discourse on both the economic disaster and the economic recovery. One reason is that CDFIs have not done a good job of measuring performance nor of publicizing it. Many institutions do not track their performance, and there remains no systemic collection of performance data. Furthermore, other than CDFI banks and credit unions, CDFI financials vary greatly and are thus non-comparable.

There are a number of nascent solutions to this problem: Opportunity Finance's CARS rating system, whic now rates 43 CDFls of varying sizes on both financial performance and impact, the risk ratings produced by the Com Measures for com out a broeder system of public performance mever, without a broader system of pubic peffomance measuren brious to community bankers and advocates: Comnunity finance performs more steadily and successfully over the ong haul relative to many other financial opportunities. This was true long before the current downturn, and appa the continues to be the case.

There should be a sense of urgency regarding this fundamental problem. Without better performance data, CDFIs will be at a disadvantage in the upcoming debate on hancial services reform. Moreover, given the skittishness CDFI particiption when the capital markets become unfrozen.

Community finance advocates have also done a poor job of taking up space in the public debate. Despite the fact that many in the community finance world had warned for years about the growth of inappropriate mortgage lending, they were often ignored. Similarly, the push to make high quality financial services broadly available to low-income populations with severe liquidity needs and limited financial understanding received little more than lip service. On the other side, those who blame the Community Reinvestment Act for the current financial debacle were able to occupy the airwaves and frame the debate in spite of their lack of data -and indeed in the face of overwhelmingly contradictory data.

The upcoming debate on financial services reform presents an opportunity to contest this persistent and disingenuous line of attack. The Boston and San Francisco Federal Reserve Banks have collaborated on a volume in which many aspects of CRA's future are considered. Going further, community finance advocates should begin to aggressively make the case that an affirmative obligation by all financial services institutions to serve all communias is the necessity of government support in ecs rorm, as is the necessity of governive.

What Does Community Finance Need Now?

What needs to be done to enable community finance to both survive and grow - to fill not only the current dire needs, but also provide financial support for the future in a manner that helps the country avoid the mistakes of the recent past? And where do things seem to be headin Washington with respect to meeting these needs? Most important, community financial institutions need equily. For ${ }^{2}$ asons of scale aniecause of the relative ported community finance in the past the federal sovernment must step up. This can be done through a fuller deployment of Troubled Asset Relief Program mey including an allocation to CDFIs through the CDFI Fund. Beyond
TARP, the CDFI Fund's appropriation must be increased, and the Fund must be able to support CDFIs at scale. Two useful steps, taken temporarily for stimulus funds, but appropriate also for 2010 appropriations, would be to increase the current limit on CDFI funding of $\$ 5$ million over thr years to a family of entities and -at least temporarily in recognition of the financial stress of traditional funders-
modify the matching requirement. With larger aming

Wh be a need to a or credit unions. Whether this an be effectively done primarily through the self-regulatory mechanisms we cirrently have primarily CARS and the two major networks NeighborWorks and Housing Partnership Network, is aquestion CDFIs need to be prepared to face. Second, there needs to be additional project-based and debt funding. The New Markets Tax Credit (NMTC) has worked far better than many expected, given the shallow nature of the subsidy and the complexities that arise from the NMTC's flexibility, but it has been vastly oversubscribed. There are many projects that are "shovel-ready" awaiting an increase in both the current round and future rounds. In addition, the credit needs to be extended substantially or made permanent. Additional tweaks in the program may be necessary to make it effective in a far less leveraged world, including bringing more of the cred forward.

As important is the need to improve the Low-Incom Housing Tax Credit (LIHTC). Fortunately, there are applicable "shovel-ready" projects. What is needed is a push to make new project investments attractive again; this is especilly hand the curent situntion is foring a sious re-think the structure of support for affordiole rental housing. question stands: Is the distribution of tax credits, wh. have largely been supported by two quasi-gover, which buyers, the most appropriate course or should the goval ment support affordable rental housing more directly with appropriations?

Community finance would also benefit from more funding of infrastructure (including community facilities) and "green" projects. The question for Congress, the Executive and community finance will be whether the forms of funding and eligible projects will be such that those close to the needs will be able to access them efficiently. While there will certainly be a need to leverage whatever funding is provided, the era of 20:1 leverage is almost certainly over. The capital markets, when they unfreeze, will, appropriately, want to see more support behind the debt financin they provide.
Last summer's housing bill provided CDFIs with access to the Home Loan Bank System. But implementation has been slow, in part because CDFI collateral is generally not of the sort the Home Loan Banks like to see. But Congres knew that when they extended eligibility; in an era when the Federal Reserve is accepting collateral that all parties agree has no current discernable
CDFI loans should look golden.

CDFIs also require new funding ideas in order to acces broader markets. New debt funding may prove difficult, as igher than has been the case. A greater emphasis must be placed on social investments as a strategy to carry the bulk of the load now as well as to increase the equity base in the of the load now, as well as to increase the equity
future as capital markets begin to unfreeze.

Finally, community finance needs a better collective infrastructure. Institutions must find ways to enhance collective functions. Some examples already exist: the risk management systems of NeighborWorks and ShoreBank for their affiliates and Community Reinvestment Fund for its lender partners; Opportunity Finance Network's CARS rating system and policy work; Housing Partnership Network's and NeighborWorks insurance projects; the Federation of Community Development Credit Union's secondary mortgage market; the training done by many of these organizations. But far more is needed. The Carsey Institute and the Aspen Institute are starting a project tha will provide additional opportunities to scale up through collective action.

Conclusion

Many communities in the United States face devastation from the current housing crisis, exacerbated by the deep recession, but communities served by CDFIs have been many of these communities were brought back to health many of these communities were brought back to heal
over the past 30 years through the diligent, consistent, over the past 30 years through the diligent, consistent,
respectful efforts of CDFIs and other community financial institutions, and their customers, clients and partners. In institutions, and their customers, clients and partners. In
order to continue to serve the neighborhoods and people that so need them, community financial institutions will need to work together as never before. The case needs to be made that these institutions can deliver quickly, intelligently and responsibly-and can do so as well or better than others who are receiving government help. To have this opportunity, CDFIs and their brethren will need new strages to tell he story of their successes-with supporing detail-loudly and clearly. 
ABOUT THE AUTHORS

Ellen Seidman is Executive Vice President, National Program and Partnership Development at ShoreBank Corporation and a Senior Fellow at the New America Foundation.

Mark Huelsman is Program Associate at the New America Foundation.

\section{ANIV UN NEW HITY}

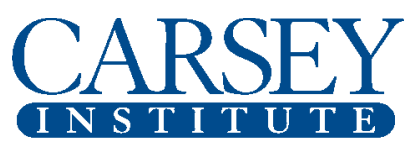

Building knowledge for families and communities

The Carsey Institute at the University of New Hampshire conducts independent, interdisciplinary research and communicates its findings to policymakers, practitioners and the general public.

Huddleston Hall

73 Main Street

Durham, NH 03824

(603) $862-2821$

www.carseyinstitute.unh.edu

The Carsey Institute Reports on Community Development are supported by the Annie E. Casey Foundation, the Ford Foundation, and the W.K. Kellogg Foundation. 